\title{
U.S. Geological Survey Great Lakes Science Forum- Summary of Remaining Data and Science Needs and Next Steps
}

Open-File Report 2021-1096 



\section{U.S. Geological Survey Great Lakes Science Forum-Summary of Remaining Data and Science Needs and Next Steps}

By Leon M. Carl, Jon E. Hortness, and Russell M. Strach

Open-File Report 2021-1096 


\section{U.S. Geological Survey, Reston, Virginia: 2021}

For more information on the USGS - the Federal source for science about the Earth, its natural and living resources, natural hazards, and the environment—visit https://www.usgs.gov or call 1-888-ASK-USGS.

For an overview of USGS information products, including maps, imagery, and publications, visit https://store.usgs.gov/.

Any use of trade, firm, or product names is for descriptive purposes only and does not imply endorsement by the U.S. Government.

Although this information product, for the most part, is in the public domain, it also may contain copyrighted materials as noted in the text. Permission to reproduce copyrighted items must be secured from the copyright owner.

Suggested citation:

Carl, L.M., Hortness, J.E., and Strach, R.M., 2021, U.S. Geological Survey Great Lakes Science Forum-Summary of remaining data and science needs and next steps: U.S. Geological Survey Open-File Report 2021-1096, 4 p., https://doi.org/10.3133/ofr20211096.

ISSN 2331-1258 (online) 


\section{Contents}

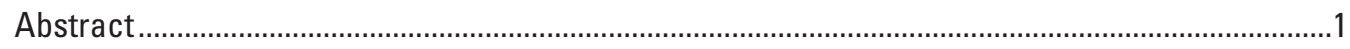

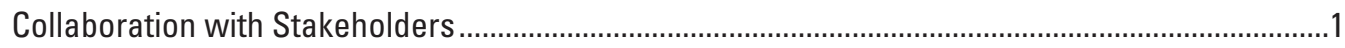

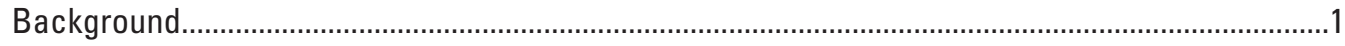

Opportunities to Improve Data Gaps and Address Areas of Concern ................................................2

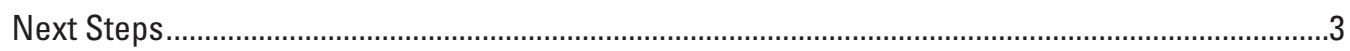

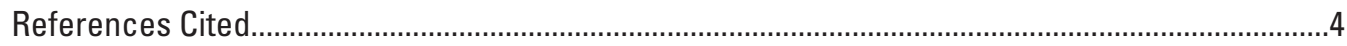

\section{Abbreviations}

EPA U.S. Environmental Protection Agency

GLRI Great Lakes Restoration Initiative

HAB harmful algae bloom

IJC International Joint Commission

NOAA National Oceanic and Atmospheric Administration

USGS U.S. Geological Survey 



\section{U.S. Geological Survey Great Lakes Science Forum- Summary of Remaining Data and Science Needs and Next Steps}

By Leon M. Carl, Jon E. Hortness, and Russell M. Strach

\section{Abstract}

A U.S. Geological Survey-led assessment of data gaps and science needs across the Great Lakes ecosystem indicated the following:

- Expanded data collection or monitoring would provide basic ecosystem, social, and public health data to manage the Great Lakes system and to develop and test models and decision support tools.

- New science and advanced technologies (for example, sensors and high-performance computing capability) would improve the understanding of critical threats, such as harmful algae blooms and high-water levels.

Although there is significant scientific knowledge in specific areas or for specific topics, managers could use improved models and decision support tools, strengthened by extensive data collection and developed at multiple scales, to better inform decision making in the future. Enhanced coordination of agency efforts and associated data collection across data types (for example, prey fish populations and water levels) is needed to effectively manage the Great Lakes.

This report highlights the data gaps; benefits of better, more structured coordination; and areas of concern specifically related to data collection/measurement and science efforts. It summarizes and analyzes stakeholder feedback and information from review of scientific literature. Finally, the report outlines steps necessary to create an integrated Great Lakes science plan.

\section{Collaboration with Stakeholders}

To assess the status of data gaps across the Great Lakes ecosystem, the U.S. Geological Survey (USGS) engaged with partners and regional stakeholders, including 18 academic scientists, the International Joint Commission (IJC), the Great Lakes Commission, the Great Lakes Fishery Commission, the Healing Our Waters Coalition, the Conference of
Great Lakes and St. Lawrence Governors and Premiers, the U.S. Environmental Protection Agency (EPA), and the National Oceanic and Atmospheric Administration (NOAA). The USGS sent correspondence to 42 Tribes with an interest in the Great Lakes and contacted the Chippewa Ottawa Resource Authority, the Great Lakes Indian Fish and Wildlife Commission, and the 1854 Treaty Authority. The USGS presented to the Partners in Action Conference of the Bureau of Indian Affairs and the North American Indian Fish and Wildlife Conference and briefed the Great Lakes Restoration Initiative (GLRI) Regional Working Group.

\section{Background}

Science research, resource protection, and landscapelevel restoration have improved in the Great Lakes region under the GLRI. Although some GLRI funding is provided for science to support management decisions, the emphasis of the GLRI is to address known problems with funding prioritized for physical restoration efforts. Approximately 5 to 10 percent of all Federal agency funding (including, but not limited to, the GLRI) in the Great Lakes is for science activities. Identifying opportunities for improved coordination would improve implementation of science to assist resources managers on the Great Lakes.

The Great Lakes Water Quality Agreement with Canada (co-led by the EPA and Environment and Climate Change Canada) (U.S. Environmental Protection Agency, 2021) is designed to improve or maintain the quality of water across the Great Lakes. The IJC has authority to manage lake levels and flows in the Great Lakes and other transboundary basins.

The Great Lakes Fishery Commission, working with the U.S. Fish and Wildlife Service and Fisheries and Oceans Canada, has controlled sea lamprey (Petromyzon marinus) populations in the Great Lakes for many years. Similar science-based approaches (for example, to address invasive mussels, phragmites, and HABs) are forming or underway to promote control of other invasive species and other critical issues. 


\section{Opportunities to Improve Data Gaps and Address Areas of Concern}

Data collection and monitoring-Although the Great Lakes have been studied extensively in specific areas or for specific purposes, substantial gaps in overall scientific knowledge affect the ability to adequately plan for restoration, mitigation, and protection. These gaps are due, in part, to a lack of basic measures of ecosystem, economic, and social data (that is, regular monitoring).

Currently (2021), open water data collection includes the following:

- Annual fish stock assessment by USGS and partners on all lakes. These surveys are coordinated by the Council of Lake Committees, made up of the State, Tribal, and Provincial fisheries managers.

- Annual spring and summer general assessments of water quality (for example, nutrients) and the lower trophic levels (for example, plankton) on each lake. These surveys are conducted by the EPA with university and Federal partners. Other agencies (for example, NOAA) conduct annual monitoring of the lower trophic levels in subbasins of some lakes (for example, southern Lake Michigan).

- Periodic (every 5 years) intensive assessments of water quality (for example, nutrients) and the lower trophic levels (for example, plankton), with other measurements taken for individual study use in different lakes at irregular intervals. Coordinated by the EPA and Environment and Climate Change Canada, the surveys collect biophysical measures including long-term monitoring of lower food webs, invasive species, and HABs in specific study locations.

- Limited Federal, university, municipal, and privatesector fixed sites (for example, buoys, NOAA weather stations, water level gauges) may take continuous readings of parameters (primarily physical) during the open water season.

Coordination of the above efforts by different organizations is limited by mission constraints and authorities of the various Federal, State, municipal, Tribal, and private entities managing those sites.

Nearshore and tributary surveys have been obtained at irregular intervals for different purposes. Other than some water-quality and discharge data collected on select tributaries by the USGS (Robertson and others, 2018) and other entities, such as Heidelberg University in Ohio (Heidelberg University, 2021), monitoring of water and nutrient flow in the watersheds is limited. States and some Tribes monitor some tributaries, but information is only shared through reporting systems such as the Environmental Quality Information System. The general lack of information impedes the development and testing of models (for example, Soil and Water Assessment Tool and Spatially Referenced Regression on Watershed Attributes) to guide nutrient reduction and land restoration efforts. In many areas, an absence of streamflow information inhibits the modeling of potential changes in watershed hydrology and nutrient and sediment loading. Generally, Great Lakes Basin hydrology is poorly characterized, causing difficulties in communicating water level issues and potential economic effects of climate change on shipping, water infrastructure, and private property. Water-quality information is also collected by municipalities at water supply intakes (for example, Toledo) and powerplant intakes, and although there are individual State and Provincial standards for those programs, the standards are not consistent across jurisdictions.

Although there are several academic studies of winter limnology (Twiss and Stryszowska, 2016), a remarkably small amount of data exist on any parameters during the winter other than satellite observation and water intake measurements owing to ice cover on all five lakes. This lack of data creates information gaps about topics such as early spring plankton blooms that affect larval fish survival or algal growth that may lead to HABs. Advancements in underwater autonomous and continuous recording technologies represent one area in which these knowledge gaps can be closed with existing or emerging technology.

Finally, economic and social data and opinions are collected periodically across the Great Lakes region to measure the collective value of the lakes to the general public; however, the integration of social science data with other ecosystem data is uncommon.

A consensus from partners and stakeholders is that improved data collection (environmental, economic, social, and public health) in support of resource managers (for example, management of the $\$ 7$ billion sport fishery) is needed. This data collection improvement applies to scale, geographic coverage or density, periodicity, and range of what is measured. Several reviews and synthesis articles (Cotner and others, 2017; Steinman and others, 2017; Sterner and others, 2017) have outlined challenges related to measurement/ monitoring, conceptual frameworks, stressors, and indicator measures that could be a starting point for science plan discussion:

- The need exists to enhance and expand consistent monitoring programs and standards across the Great Lakes.

- Basinwide, there are few early detection and rapid response teams for invasive species.

- There are few warning systems to predict water-quality crises (for example, the 2014 shutdown of the Toledo water treatment plant; Sterner and others, 2017), and existing models have limited ability to predict contamination or other issues that affect recreation or the quality of Tribal, commercial, and recreational fisheries.

- More structured coordination is needed across basins to inform current and future management decisions. 
Science, frameworks, and modeling-The Great Lakes stressors include overfishing, invasive species, changes in land use, industrial and residential pollution, and climate change. Large-scale Earth and biological system simulations built on a foundation of big data and high-performance computing capabilities can help address the effects of those stressors.

Although substantial work has been completed to address those stressors, broad areas within each stressor and across stressors would benefit from more science knowledge. Stressors likely interact in unknown ways that mask or exacerbate ecosystem dysfunction. Additional data collection and modeling would inform future management actions to address these types of stressors.

There is also consensus from partners and stakeholders that conceptual frameworks or models will help delineate ecosystem structure and function, particularly regarding management, restoration, and remediation. These models and frameworks, incorporating large-scale datasets and high-performance computing, could help resource managers understand interactions and changes across the system, allowing them to prioritize restoration and protection where investments would have the greatest value. Two examples for which additional data and modeling would benefit managers are the increasing trend in precipitation and the general lack of information on groundwater quality and quantity:

- Increasing trends in precipitation and more intense storm events may result in increased nutrient loading, even as more nutrient-reduction practices are put in place and the long-term water levels across the Great Lakes continue to increase. Problems may also occur from sewer overflows driven by large storm events, fish and wildlife kills caused by increased pollution, and HAB-contaminated water supplies.

- Little to no groundwater-quantity or -quality information is available to help manage water availability pursuant to the Great Lakes Compact (Great Lakes St. Lawrence Governors and Premiers, 2021; Wisconsin Department of Natural Resources, 2021) and other regional and local needs. The extent to which groundwater quantity and quality affect the overall function of the Great Lakes system is currently unknown.

At present, models or frameworks are often used to help address specific issues in locations of concern, with no overarching approach across the Great Lakes system. The NOAA has developed lake circulation models-including the effects of waves and ice-for forecasting purposes (National Oceanic and Atmospheric Administration - Great Lakes Environmental Research Laboratory, 2021), as well as limited models for predicting the effects of HABS, hypoxia, and invasive species, but those models cannot support a full ecosystem management approach, in part because of an absence of data. Expert systems, such as the USGS Spatially Referenced Regression on Watershed Attributes model (U.S. Geological Survey, 2021), are useful to test management actions on subecosystem scale in highly perturbed systems, such as the Saginaw, Fox, and Maumee River Basins. As one current example under the Great Lakes Water Quality Agreement with Canada, the U.S. and Canadian partners are using conceptual models and an adaptive management framework to support reduction of nutrient inputs into the Western Basin of Lake Erie to address HABs issues (U.S. Environmental Protection Agency, 2021). In addition, the GLRI has a science component to its 5-year action plans (U.S. Environmental Protection Agency, 2019) that helps articulate those needs as they relate to the specific GLRI efforts; however, it does not include a more general framework for the Great Lakes.

\section{Next Steps}

Creation of the Great Lakes science plan-The USGS estimates that it will take 5 years to initiate, draft, adopt, and administer a collaborative Great Lakes science plan. An integrated group that includes U.S., Canadian, Tribal, and First Nation participants could best articulate science needs, priorities, and gaps for the plan. The consensus among partners is that the plan be focused across all jurisdictional boundariesecosystem based, management and policy oriented, consensus based, and accountable.

Several existing management and science forums and science planning exercises could inform this effort. The IJC (International Joint Commission, 2020) and the Conference of Great Lakes and St. Lawrence Governors and Premiers (Great Lakes St. Lawrence Governors and Premiers, 2019) are currently performing science planning exercises that would likely be of value to this effort. The Great Lakes Observation System has a Smart Great Lakes Initiative (Great Lakes Observing System, 2021) focusing on coordination and integration of data platforms. Working with those and other efforts will strengthen the plan.

Implementation of the Great Lakes science plan-The USGS estimates that implementing the Great Lakes science plan would take 5 years. Based on feedback from stakeholders while developing this report, a new plan would likely focus priority science information in three categories:

1. Creation of new science and exploration of advanced technology

2. Address fundamental deficiencies (for example, expanding data collection)

3. Develop and test better/new models and decision support tools

Examples of priority work could include (1) expansion of existing monitoring programs and assessments to increase frequency and spatial coverage; (2) initiation of critical science activities for under-ice conditions during the months when the lakes are often covered by ice; (3) deployment of 
advanced and autonomous technologies and new tools to more efficiently obtain biological, physical, and chemical information; and (4) expansion of public health assessments.

\section{References Cited}

Cotner, J.B., Weinke, A.D., and Biddanda, B.A., 2017, Great Lakes, Science can keep them great: Journal of Great Lakes Research, v. 43, no. 5, p. 916-919. [Also available at https://doi.org/10.1016/j.jglr.2017.07.002.]

Great Lakes Observing System, 2021, Smart Great Lakes: accessed September 2021 at https://glos.org/priorities/ smart-great-lakes/.

Great Lakes St. Lawrence Governors and Premiers, 2019, Great Lakes St. Lawrence Regional Body \& Compact Council-Science Strategy: accessed September 2021 at https://www.glslcompactcouncil.org/media/2gyle2b2/rb-ccscience-strategy-2019.pdf.

Great Lakes St. Lawrence Governors and Premiers, 2021, Great Lakes Agreement and Compact: accessed September 2021 at https://gsgp.org/projects/watermanagement/great-lakes-agreement-and-compact/.

Heidelberg University, 2021, National Center for Water Quality Research, The Heidelberg Tributary Loading Program: accessed September 2021 at https://ncwqr.org/ monitoring/.

International Joint Commission, 2020, Science Advisory Board Research Coordination Committee: accessed September 2021 at https://ijc.org/sites/default/files/2021-02/ SAB-RCC_MeetingSummary_Dec-17-2020.pdf.

National Oceanic and Atmospheric Administration - Great Lakes Environmental Research Laboratory, 2021, Great Lakes Coastal Forecasting System-Next generation: accessed September 2021 at https://www.glerl.noaa.gov/res/ Programs/ipemf/GLCFS_nextgen.html.

Robertson, D.M., Hubbard, L.E., Lorenz, D.L., and Sullivan, D.J., 2018, A surrogate regression approach for computing continuous loads for the tributary nutrient and sediment monitoring program on the Great Lakes: Journal of Great Lakes Research, v. 44, no. 1, p. 26-42. [Also available at https://doi.org/10.1016/j.jglr.2017.10.003.]
Steinman, A.D., Cardinale, B.J., Munns, W.R., Jr., Ogdahl, M.E., Allan, J.D., Angadi, T., Bartlett, S., Brauman, K., Byappanahalli, M., Doss, M., Dupont, D., Johns, A., Kashian, D., Lupi, F., McIntyre, P., Miller, T., Moore, M., Muenich, R.L., Poudel, R., Price, J., Provencher, B., Rea, A., Read, J., Renzetti, S., Sohngen, B., and Washburn, E., 2017, Ecosystem Service in the Great Lakes: Journal of Great Lakes Research, v. 43, no. 3, p. 161-168. [Also available at https://doi.org/10.1016/j.jglr.2017.02.004.]

Sterner, R.W., Ostrom, P., Ostrom, N.E., Klump, J.V., Steinman, A.D., Dreelin, E.A., Vander Zanden, M.J., and Fisk, A.T., 2017, Grand challenges for research in the Laurentian Great Lakes: Limnology and Oceanography, v. 62 , no. 6, p. 2510-2523. [Also available at https://doi.org/ 10.1002/lno.10585.]

Twiss, M.R., and Stryszowska, K.M., 2016, State of emerging technologies for assessing aquatic condition in the Great Lakes - St. Lawrence River system: Journal of Great Lakes Research, v. 42, p. 1470-1477. [Also available at https://doi.org/10.1016/j.jglr.2016.10.002.]

U.S. Environmental Protection Agency, 2019, Great Lakes Restoration Initiative-Action Plan III: accessed September 2021 at https:/www.epa.gov/sites/default/files/ 2019-10/documents/glri-action-plan-3-201910-30pp.pdf.

U.S. Environmental Protection Agency, 2021, Great Lakes Water Quality Agreement (GLWQA): accessed September 2021 at https://www.epa.gov/glwqa.

U.S. Geological Survey, 2021, SPARROW modelingEstimating nutrient, sediment, and dissolved solids transport: accessed September 2021 at https://www.usgs.gov/ mission-areas/water-resources/science/sparrow-modelingestimating-nutrient-sediment-and-dissolved?qt-science center_objects $=0 \#$ qt-science_center_objects.

Wisconsin Department of Natural Resources, 2021, Great Lakes Compact and diversions: accessed September 2021 at https://dnr.wisconsin.gov/topic/WaterUse/Compact.html. 
For more information about this publication, contact: Director, Midwest Regional Director's Office U.S. Geological Survey

5957 Lakeside Boulevard

Indianapolis, IN 46278

$317-600-2753$

For additional information, visit: https://www.usgs.gov/ unified-interior-regions/region-3

Publishing support provided by the Rolla Publishing Service Center 
